${ }^{2}$ Kujawska Szkoła Wyższa we Włocławku, Wydział Nauk o Zdrowiu

${ }^{3}$ Państwowa Wyższa Szkoła Zawodowa we Włocławku, Instytut Nauk o Zdrowiu

\title{
Satysfakcja pacjentów z pielęgniarskiej opieki przedoperacyjnej
}

\author{
Patients' satisfaction with preoperative nursing care
}

\section{Streszczenie}

Wstęp. Istotnym elementem zarządzania jakością w zakładach opieki zdrowotnej stał się pomiar satysfakcji pacjenta z otrzymanych świadczeń medycznych. Badanie satysfakcji pacjenta jest badaniem subiektywnych ocen pacjenta opartych na indywidualnym doświadczeniu, wymaganiach i oczekiwaniach. Dla pacjenta jakość usług medycznych zależy od kwalifikacji lekarzy i pielęgniarek, od przebiegu procesu terapeutycznego oraz od poprawy stanu zdrowia. Pacjent ocenia respektowanie praw pacjenta, postawę personelu, proces pielęgnowania, dostępność i warunki udzielania świadczeń, wygodę korzystania ze świadczeń, sprawność organizacyjną w udzielaniu świadczeń oraz uzyskane efekty zdrowotne.

Cel. Celem badań jest poznanie i analiza poziomu satysfakcji pacjenta z przedoperacyjnej opieki pielęgniarskiej.

Materiał i metody. Badania przeprowadzono w Specjalistycznym Szpitalu Wojewódzkim w Ciechanowie. Grupę badaną stanowiło 60 pacjentów będących w okresie przedoperacyjnym przebywających w 4 oddziałach zabiegowych. Dla wykonania badań wykorzystano metodę sondażu diagnostycznego $\mathrm{z}$ użyciem kwestionariusza ankiety własnej konstrukcji.

Wyniki. Na podstawie wykonanych badań stwierdzono, że pacjenci będący w okresie przedoperacyjnym prezentują wysoką satysfakcję z opieki pielęgniarskiej świadczonej w oddziale szpitalnym. Na poziom satysfakcji pacjentów wpływają określone czynniki socjodemograficzne.

Wnioski. 1. Satysfakcja pacjentów z opieki pielęgniarskiej przedoperacyjnej jest wyższa w grupie mężczyzn niż w grupie kobiet. 2. Satysfakcja pacjentów z opieki pielęgniarskiej przedoperacyjnej jest wyższa w grupie osób będących w związku małżeńskim jak i będących w stanie wolnym w porównaniu z grupą osób owdowiałych. 3. Satysfakcja pacjentów z opieki pielęgniarskiej przedoperacyjnej jest wyższa wśród osób mieszkających na wsi w porównaniu z grupą osób mieszkających w mieście. 4. Satysfakcja pacjentów z opieki pielęgniarskiej przedoperacyjnej jest jednakowo wysoka wśród osób mających jako źródło dochodu stałą pracę jak i wśród osób mających okresową pracę lub osób, których źródłem utrzymania jest emerytura.

\footnotetext{
Abstract

Introduction. The measurement of patient satisfaction with the medical services received has become an important element of quality management in health care. Patient's satisfaction test is a study of patient's subjective assessments based on individual experience, requirements and expectations. For the patient, the quality of medical services depends on the qualifications of doctors and nurses, on the course of the therapeutic process as well as on the improvement of health. The patient assesses the respect for the
} 
rights of the patient, the attitude of the staff, the nursing process, and the availability and conditions for granting services, convenience in the services, organizational efficiency in the provision of services and the resulting health effects.

Aim. The aim of the research is to understand and analyze the level of patient's satisfaction with preoperative nursing care.

Material and methods. The study was conducted at the Specialist Hospital in Ciechanów. The study group included 60 patients preoperatively staying in 4 surgical wards. In the study the diagnostic survey method using a questionnaire of our own design was applied.

Results. Based on the studies it has been found that patients in the preoperative period present high satisfaction with nursing care provided in a hospital ward. The level of satisfaction of patients is affected by certain socio-demographic factors.

Conclusions. 1. Patients' satisfaction with preoperative nursing care is higher in men when compared to women. 2. Patients' satisfaction with preoperative nursing care is higher among those who are married and who are unmarried, compared with a group of respondents being a widow or widower. 3. Satisfaction of patients with pre-operative nursing care is higher among those living in rural areas compared with those living in the city. 4. Patients' satisfaction with preoperative nursing care is equally high among respondents with a source of income from a permanent job as well as among those with temporary jobs or people whose source of income is based on retirement benefits.

Słowa kluczowe: pacjent, satysfakcja, opieka pielęgniarska

Keywords: patient, satisfaction, nursing care

\section{Wstęp}

Jakość opieki może być oceniana względem świadczeniodawcy jak i świadczeniobiorcy. Sposobem oceny jakości opieki z punktu widzenia pacjenta czyli świadczeniobiorcy jest badanie jego satysfakcji. Satysfakcja może być definiowana jako „przyjemność jaką odczuwamy, gdy osiągniemy coś, na czym nam zależało lub jest to też zadośćuczynienie za wyrządzoną komuś krzywdę lub za obrazę”. Pojęcie to rozumiane jest także jako „wyobrażenie, pogląd, zdanie o czymś, rozumienie, uświadamianie sobie czegoś”, a także może to być „myślowe odzwierciedlenie całościowego ujęcia istotnych cech przedmiotów czy zjawisk, myślowy odpowiednik nazwy". Poczucie satysfakcji jest zjawiskiem psychicznym oraz subiektywnym uczuciem przyjemności i zadowolenia, które przejawia się w postaci pewnych istotnych postaw, zachowań, reakcji [1,2].

Analizując pojęcie satysfakcji pacjenta należy ustalić co jest istotą tego uczucia oraz jakie ważne cechy je odzwierciedlają. Jest to miara opinii chorego lub jego rodziny na temat udzielonej opieki medycznej. Na gruncie pielęgniarskim akceptowana i szeroko stosowana jest definicja N. Risser, zgodnie z którą satysfakcja pacjenta z opieki pielęgniarskiej to stopień zgodności między jego oczekiwaniami a percepcją opieki, którą realnie otrzymuje. Zależy ona od różnicy między tym, co uzyskuje chory, a jego subiektywnymi oczekiwaniami. Jeżeli różnica jest dodatnia oznacza to, że pacjent jest usatysfakcjonowany, jeżeli różnica jest ujemna świadczy to o jego niezadowoleniu. Oczekiwania pacjentów mają zatem wpływ na określanie poziomu satysfakcji z otrzymanej opieki. Oczekiwania takie mogą powstawać na podstawie wyobrażenia o idealnej opiece lub wynikać z wcześniejszych doświadczeń związanych z systemem ochrony zdrowia. Jedną z istotnych kwestii związanych z pomiarem satysfakcji pacjentów z uzyskanych świadczeń jest określenie potencjalnego wpływu indywidualnych oczekiwań na ocenę poziomu zadowolenia [2,3].

Jakość świadczonych usług medycznych oceniana jest na podstawie określonych standardów, obiektywnych danych i wskaźników ustalonych przez świadczeniodawców, kadrę 
kierowniczą, jednostki akredytujące szpitale, ewentualnie Narodowy Fundusz Zdrowia. Natomiast satysfakcja pacjenta jest subiektywnym postrzeganiem i oceną jakości opieki świadczonej w placówce według jego własnych, subiektywnych kryteriów. Należy jednak pamiętać, że to pacjent i jego potrzeby, oczekiwania, pragnienia są w centrum uwagi personelu medycznego oraz to, że jest on główną postacią procesu. W związku z tym posiada on prawo do współdecydowania o przebiegu procesu leczenia i pielęgnowania, jak również oceny i decydowania o jakości tej opieki [4].

Okres hospitalizacji charakteryzuje największe natężenie bezpośrednich kontaktów pielęgniarki z chorym. W dużej mierze to właśnie od pielęgniarki zależy jak pacjent będzie radził sobie $\mathrm{w}$ przebiegu choroby, jak zniesie uciążliwości związane $\mathrm{z}$ procesem diagnozowania i leczenia, jak zostanie przygotowany do powrotu do środowiska domowego. Jakość opieki pielęgniarskiej stanowi znaczącą składową ogólnego wymiaru jakości opieki świadczonej w placówce ochrony zdrowia. Współcześnie pacjenci domagają się świadczeń, które spełniają ich wymagania, a tym samym podlegają weryfikacji w ramach systemu zarządzania jakością. Zarządzanie jakością przyczynia się do poprawy pozycji rynkowej oraz wizerunku i prestiżu placówki. Prowadzi także do zwiększenia wydajności oraz usprawnienia obsługi pacjentów i wzrostu ich zadowolenia [5].

Istotnym elementem zarządzania jakością w zakładach opieki zdrowotnej stał się pomiar satysfakcji pacjentów. Badanie poziomu ich zadowolenia to analiza subiektywnych ocen chorych oparta na ich indywidualnym doświadczeniu, wymaganiach i oczekiwaniach. W opinii pacjenta jakość usług medycznych zależy od kwalifikacji lekarzy i pielęgniarek, warunkuje przebieg procesu terapeutycznego oraz poprawę stanu zdrowia. Chory ocenia respektowanie jego praw, postawę personelu, proces pielęgnowania, dostępność, warunki, wygodę i sprawność organizacyjną w udzielaniu świadczeń oraz uzyskane efekty zdrowotne.

Elementem, na którym opiera się cały proces zapewniania jakości opieki pielęgniarskiej, stanowią standardy opieki pielęgniarskiej, które są normami, regułami i zasadami postępowania w opiece nad poszczególnymi grupami pacjentów. Istotą standardu jest ukierunkowanie go na pożądany, wartościowy poziom, który zmierza $\mathrm{w}$ kierunku ideału, ale $\mathrm{z}$ zachowaniem osiągalności i realistyczności. Jakość opieki pielęgniarskiej postrzegana odczuwana przez pacjenta jest jednym z mierników całościowej opieki świadczonej w placówce ochrony zdrowia. Chory ma prawo oczekiwać i wymagać wysokiego poziomu opieki oraz uczestniczyć w podejmowaniu decyzji dotyczących jej przebiegu [6].

Celem badań, których wyniki zaprezentowano w opracowaniu była analiza poziomu satysfakcji pacjentów z przedoperacyjnej opieki pielęgniarskiej.

\section{Materiał i metody badań}

Badania przeprowadzono w Specjalistycznym Szpitalu Wojewódzkim w Ciechanowie w okresie od stycznia do kwietnia 2013 roku. Na wykonanie badań uzyskano zgodę Komisji Bioetycznej Kujawsko-Pomorskiej Okręgowej Izby Lekarskiej w Toruniu (21/KB/2012). Grupę badaną stanowili pacjenci będący w okresie przedoperacyjnym przebywający w Oddziale Chirurgii Ogólnej, Oddziale Urologicznym, Oddziale Ginekologicznym oraz w Oddziale Laryngologicznym. W badaniach wykorzystano metodę sondażu diagnostycznego z użyciem kwestionariusza ankiety własnej konstrukcji zawierającego 17 pytań zamkniętych jednokrotnego i wielokrotnego wyboru. Analizę statystyczną wyników badań wykonano przy użyciu programu Microsoft Office Excel 2007 z zastosowaniem testu chi kwadrat $\left(\chi^{2}\right)$ dla zbadania zależności pomiędzy dwiema zmiennymi nominalnymi. Przyjęto dla wszystkich analiz współczynnik istotności na poziomie $p \leq 0,05$. 


\section{Wyniki badań}

W badaniach uczestniczyło 60 pacjentów, w tym kobiety stanowiły $45 \%$, a mężczyźni 55\% ogółu badanych. Wiek respondentów kształtował się od 20 do 80 lat, a dominujący przedział wiekowy dotyczył 71-80 lat (21,7\%). Największą grupę pod względem stanu cywilnego stanowili badani pozostający w związku małżeńskim $(56,7$ \%). Wśród respondentów dominowały osoby z wykształceniem podstawowym $(46,7 \%)$ oraz mieszkańcy miast $(56,7 \%)$. Podstawowym źródłem utrzymania badanych były dochody z pracy stałej $(35,0 \%)$.

Zdecydowana większość respondentów (96,3\%) była zadowolona $\mathrm{z}$ opieki pielęgniarskiej świadczonej w oddziale szpitalnym w okresie przed operacją. Za najważniejszy element optymalnego przygotowania do operacji 31,7\% osób uznało zapewnienie poczucia intymności. Natomiast $26,7 \%$ respondentów podkreśliło znaczenie poziomu kultury rozmów prowadzonych z pacjentami przez pielęgniarki. W opinii $28,3 \%$ badanych każdy z powyższy aspektów był istotny. Z kolei 11,7\% chorych podkreślało znaczenie zapewnienia ciszy i spokoju, a 1,7\% pacjentów - reakcje pielęgniarek na prośby pacjentów.

Zdecydowana większość respondentów (71,7\%) twierdziła, że niczego nie trzeba zmieniać $\mathrm{w}$ pracy pielęgniarek sprawujących opiekę nad pacjentami w okresie przedoperacyjnym. Natomiast $15,0 \%$ osób było zdania, że należy zmienić wszystko, a 11,7\% uważała, że konieczna jest ścisła współpraca pielęgniarek w zakresie pomocy chorym. Wszyscy respondenci $(100 \%)$ potwierdzili, że szpital, w którym przebywali jest godny polecenia rodzinie i znajomym a także to, że doradziliby pobyt w oddziale i poddanie się operacji.

W analizie statystycznej wyników badań zbadano korelację zmiennych niezależnych (z grupy czynników socjodemograficznych) ze zmiennymi zależnymi czyli opiniami badanych na temat zadowolenia $\mathrm{z}$ opieki pielęgniarskiej przedoperacyjnej. Tabela 1 prezentuje satysfakcję respondentów z opieki w zależności od ich płci.

Tabela 1. Zadowolenie z opieki pielęgniarskiej a płeć badanych.

\begin{tabular}{|l|c|c|c|c|c|}
\hline \multirow{2}{*}{ Zadowón } & \multicolumn{2}{|c|}{ Tak } & \multicolumn{2}{c|}{ Nie } & \multirow{2}{*}{ Razem } \\
\cline { 2 - 5 } & $\mathrm{n}=59$ & $\%$ & $\mathrm{n}=1$ & $\%$ & \\
\hline kobieta & 26 & $96,3 \%$ & 1 & $3,7 \%$ & 27 \\
\hline mężczyzna & 33 & $100,0 \%$ & 0 & $0,0 \%$ & 33 \\
\hline Istotność $\chi^{2}$ & \multicolumn{3}{|c|}{1,24} & 60 \\
\hline
\end{tabular}

Źródło: opracowanie własne

Nie stwierdzono zależności istotnej statystycznie pomiędzy płcią respondentów a zadowoleniem z opieki pielęgniarskiej. Niemniej jednak wszyscy mężczyźni (100\%) i zdecydowana większość kobiet $(96,3 \%)$ potwierdzili satysfakcję z udzielanych świadczeń. Tylko 1 kobieta $(3,7 \%)$ zaprzeczyła takiej opinii.

Tabela 2 przedstawia zadowolenie z opieki w zależności od płci respondentów.

Tabela 2. Zadowolenie z opieki pielęgniarskiej a stan cywilny badanych.

\begin{tabular}{|l|c|c|c|c|c|}
\hline \multirow{2}{*}{ Stan cywilny } & \multicolumn{2}{|c|}{ Tak } & \multicolumn{2}{c|}{ Nie } & Razem \\
\cline { 2 - 6 } & $\mathrm{n}=59$ & $\%$ & $\mathrm{n}=1$ & $\%$ & \\
\hline wolny / wolna & 6 & $100,0 \%$ & 0 & $0,0 \%$ & 6 \\
\hline
\end{tabular}




\begin{tabular}{|l|c|c|c|c|c|} 
żonaty / zamężna & 34 & $100,0 \%$ & 0 & $0,0 \%$ & 34 \\
\hline wdowa / wdowiec & 18 & $94,7 \%$ & 1 & $5,3 \%$ & 19 \\
\hline rozwiedziony /rozwiedziona & 1 & $100,0 \%$ & 0 & $0,0 \%$ & 1 \\
\hline Istotność $\chi^{2}$ & \multicolumn{5}{|c|}{2,19} \\
\hline
\end{tabular}

Źródło: opracowanie własne

Nie potwierdzono zależności istotnej statystycznie między zadowoleniem z uzyskanej opieki a stanem cywilnych badanych. Wszyscy respondenci poza 1 osobą będącą wdową $(5,3 \%)$ wyrażali satysfakcję z opieki pielęgniarskiej.

W tabeli 3 zaprezentowano opinię badanych na temat zadowolenia $\mathrm{z}$ opieki z uwzględnieniem ich miejsca zamieszkania.

Tabela 3. Zadowolenie z opieki pielęgniarskiej a miejsce zamieszkania badanych.

\begin{tabular}{|l|c|c|c|c|c|}
\hline \multirow{2}{*}{ Zadowolenie } & \multicolumn{2}{|r|}{ Tak } & \multicolumn{2}{c|}{ Nie } & \multirow{2}{*}{ Razem } \\
\cline { 2 - 6 } Miejsce zamieszkania & $\mathrm{n}=59$ & $\%$ & $\mathrm{n}=1$ & $\%$ & \\
\hline Miasto & 33 & $97,1 \%$ & 1 & $2,9 \%$ & 34 \\
\hline Wieś & 26 & $100,0 \%$ & 0 & $0,0 \%$ & 26 \\
\hline Istotność $\chi^{2}$ & \multicolumn{5}{|c|}{0,78} \\
\hline
\end{tabular}

Źródło: opracowanie własne

$\mathrm{Na}$ podstawie analizy statystycznej nie stwierdzono zależności pomiędzy miejscem zamieszkania ankietowanych a ich zadowoleniem z opieki pielęgniarskiej. Niemniej jednak wszyscy mieszkańcy wsi (100\%) i zdecydowana większość osób mieszkających w mieście $(97,1 \%)$ wyraziła satysfakcję z udzielanej opieki pielęgniarskiej. Tylko jeden mieszkaniec miasta $(2,9 \%)$ nie potwierdził takiego stanowiska.

$\mathrm{W}$ tabeli 4 zaprezentowano opinię badanych na temat zadowolenia $\mathrm{z}$ opieki z uwzględnieniem źródła ich utrzymania.

Tabela 4. Zadowolenie z opieki pielęgniarskiej a źródło utrzymania badanych.

\begin{tabular}{|l|c|c|c|c|c|}
\hline \multirow{2}{*}{ Zadowolenie } & \multicolumn{2}{r|}{ Tak } & \multicolumn{2}{c|}{ Nie } & Razem \\
\cline { 2 - 6 } & $\mathrm{n}=59$ & $\%$ & $\mathrm{n}=1$ & $\%$ & \\
\hline pródło utrzymania okresowa & 9 & $100,0 \%$ & 0 & $0,0 \%$ & 9 \\
\hline praca stała & 21 & $100,0 \%$ & 0 & $0,0 \%$ & 21 \\
\hline emerytura & 7 & $100,0 \%$ & 0 & $0,0 \%$ & 7 \\
\hline Inne & 22 & $95,7 \%$ & 1 & $4,4 \%$ & 23 \\
\hline Istotność $\chi^{2}$ & \multicolumn{7}{|c|}{1,64} \\
\hline
\end{tabular}

Źródło: opracowanie własne

Analiza statystyczna nie dowiodła istotnej statystycznie zależności pomiędzy źródłem utrzymania respondentów a zadowoleniem z opieki pielęgniarskiej. Niezależnie od źródła dochodów wynikających z pracy stałej, okresowej lub posiadania uprawnień emerytalnych wszyscy badani potwierdzali satysfakcję z opieki. Tylko jedna osoba dysponująca innym źródłem utrzymania $(4,4 \%)$ nie potwierdziła takiego stanowiska. 


\section{Dyskusja}

Badanie satysfakcji pacjenta jest istotnym elementem oceny jakości świadczonej opieki zdrowotnej. Potrzeba pomiaru i oceny jakości opieki pielęgniarskiej jest faktem niekwestionowanym, jednakże nie jest to zadanie łatwe. Zainteresowanie pomiarem jakości opieki pielęgniarskiej i jej zapewnianie jest wynikiem rosnącej tożsamości zawodowej pielęgniarek i potrzebą szukania nowych, opartych na podstawach naukowych rozwiązań w praktyce zawodowej. Ponadto pomiar jakości opieki zdrowotnej to także zalecenia instytucji finansujących świadczenia opieki zdrowotnej [7].

W odniesieniu do badań własnych stwierdzono, że pacjenci są zdecydowanie zadowoleni z pielęgniarskiej opieki przedoperacyjnej. Respondenci uważają, że zostali odpowiednio przygotowani przez pielęgniarkę do zabiegu operacyjnego oraz że ułatwiono im akceptuję operacji jako metody leczenia choroby. Potwierdzają, że wyjaśniono im zasadność wykonywania badań i zabiegów. Wyniki badań własnych wskazują, że czynniki takie jak: dostępność pielęgniarek w razie potrzeby, uprzejmość, okazywanie zrozumienia i zainteresowania przez pielęgniarki, kultura rozmowy, zapewnienie intymności, reakcja na prośby chorych, szybkość reagowania mają duży wpływ na satysfakcję pacjentów z opieki przedoperacyjnej.

W toku procedury badań własnych analizowano wpływ wybranych czynników socjodemograficznych na wynik oceny opieki pielęgniarskiej przedoperacyjnej, dokonanej przez pacjentów oddziałów zabiegowych. Analiza statystyczna wyników badań własnych dowiodła, że nie istnieje istotna zależność pomiędzy zadowoleniem pacjentów z przedoperacyjnej opieki pielęgniarskiej a czynnikami socjodemograficznymi, takimi jak: płeć, stan cywilny, miejsce zamieszkania, źródło utrzymania respondentów.

W badaniach M. Motyki i współautorów wykazano duże oczekiwania pacjentów w zakresie informowania na temat własnej choroby i jednocześnie niedostateczny wynik realizacji tych oczekiwań przez lekarzy i pielęgniarki w opinii zdecydowanej większości pacjentów. W. Kapała na podstawie wyników badań w zakresie oczekiwań pacjentów hospitalizowanych wobec personelu pielęgniarskiego stwierdził, że chorzy mają problem ze sprecyzowaniem swoich oczekiwań wobec pielęgniarki. Autor wskazał, że pacjenci oczekują od pielęgniarki w największym zakresie sprawności manualnej podczas wykonywania zabiegów oraz informowania o wykonywanych czynnościach [2].

Oczekiwania pacjentów wobec pielęgniarki neurochirurgicznej badał także R. Ślusarz i współautorzy. Najistotniejsze z tych oczekiwań to: punktualność, odpowiedzialność, kultura osobista, życzliwość, przygotowanie psychiczne do zabiegu, rzetelna informacja o wykonywanych czynnościach pielęgnacyjnych, pomoc w utrzymaniu higieny, pomoc w zaspokajaniu potrzeb fizycznych, eliminowanie bólu, edukacja. Zespół badawczy R. Ślusarza i współautorów, oceniając satysfakcję pacjentów z opieki pielęgniarskiej dokonał analizy następujących aspektów opieki pielęgniarskiej: informowanie o czynnościach i zabiegach wykonywanych przez pielęgniarki, czas pielęgniarki przeznaczony dla pacjenta, szybkość reakcji na wezwanie chorego, praca pielęgniarek na dyżurach dziennych i nocnych [8].

Wyniki badań innego zespołu badawczego uwzględniają odrębne aspekty opieki pielęgniarskiej oceniane w toku badań satysfakcji pacjentów z opieki pielęgniarskiej. Należą do nich takie zagadnienia jak: poprawność wykonywania zabiegów, relacje interpersonalne, sposób przyjęcia pacjenta do oddziału, podmiotowe traktowanie pacjenta, informowanie, edukacja, zaspokajanie potrzeb egzystencjalnych, warunki hotelowe, przygotowanie pacjenta do samoopieki, poświęcanie czasu i uwagi pacjentowi, takt, kultura oraz postawa pielęgniarek wobec pacjenta [7]. 
Porównanie uzyskanych wyników badań własnych z wynikami otrzymanymi w innych ośrodkach badawczych jest utrudnione ze względu na stosowane przez zespoły autorów różnych narzędzi badawczych i różnych kryteriów doboru grupy badanej.

\section{Wnioski}

1. Satysfakcja pacjentów z opieki pielęgniarskiej przedoperacyjnej jest wyższa w grupie mężczyzn niż w grupie kobiet. Różnice te nie są istotne statystycznie.

2. Satysfakcja pacjentów z opieki pielęgniarskiej przedoperacyjnej jest wyższa w grupie osób będących w związku małżeńskim jak i będących w stanie wolnym, w porównaniu do osób owdowiałych. Różnice te nie są istotne statystycznie.

3. Satysfakcja pacjentów z opieki pielęgniarskiej przedoperacyjnej jest wyższa wśród osób mieszkających na wsi, w porównaniu do respondentów mieszkających w mieście. Różnica ta nie jest istotna statystycznie.

4. Satysfakcja pacjentów z opieki pielęgniarskiej przedoperacyjnej jest wysoka niezależnie od źródeł dochodu badanych. Różnic istotnych statystycznie nie stwierdzono.

\section{Zalecenia dla praktyki pielęgniarskiej}

W opiece pielęgniarskiej realizowanej wobec pacjentów w okresie przedoperacyjnym należy wdrażać wysoki poziom świadczeń. Zgodnie $\mathrm{z}$ oczekiwaniami pacjentów $\mathrm{z}$ oddziałów zabiegowych w opiece pielęgniarskiej należy szczególnie uwzględnić uprzejmość, życzliwość, okazywanie zainteresowania, zrozumienie problemów pacjenta, szybkość reakcji na jego prośby, zapewnienie intymności $\mathrm{w}$ czasie badań i zabiegów. Czynniki te mają znaczący wpływ na kształtowanie poziomu satysfakcji pacjentów z otrzymywanych świadczeń pielęgnacyjnych.

\section{Bibliografia / Bibliography:}

1. Słownik języka polskiego. Tom V. Wydawnictwo Naukowe PWN. Warszawa 2007.

2. Szeszycka I. Dylematy pomiaru jakości usług profesjonalnych na przykładzie usług medycznych. Antidotum. 2000;4:3-11.

3. Marcinowicz L. Satysfakcja pacjenta. Magazyn Pielęgniarki i Położnej. 2008;5:7-9.

4. Mykowska A. Satysfakcja pacjenta a jakość obsługi medycznej. Zdrowie i Zarządzanie. 2002;4(6):69-73.

5. Burda K. Analiza problematyki satysfakcji pacjenta w powiązaniu z zagadnieniami dotyczącymi jakości opieki zdrowotnej. Antidotum. 2003;01:61-80.

6. Kapała W., Chudziński S., Hyrcza S. Oczekiwania pacjentów hospitalizowanych na oddziałach zabiegowych wobec personelu pielęgniarskiego. Pielęgniarstwo Chirurgiczne i Angiologiczne. 2008;2(1):12-18.

7. Wyrzykowska M. Ocena opieki pielęgniarskiej w opinii pacjentów. Pielęgniarstwo Chirurgiczne i Angiologiczne. 2007;1(1):3-10. 
8. Wasilewski T. Subiektywna ocena wybranych aspektów satysfakcji z pobytu w szpitalu pacjentów oddziałów zabiegowych. Pielęgniarstwo Chirurgiczne i Angiologiczne. 2008;3(27):81-86. 